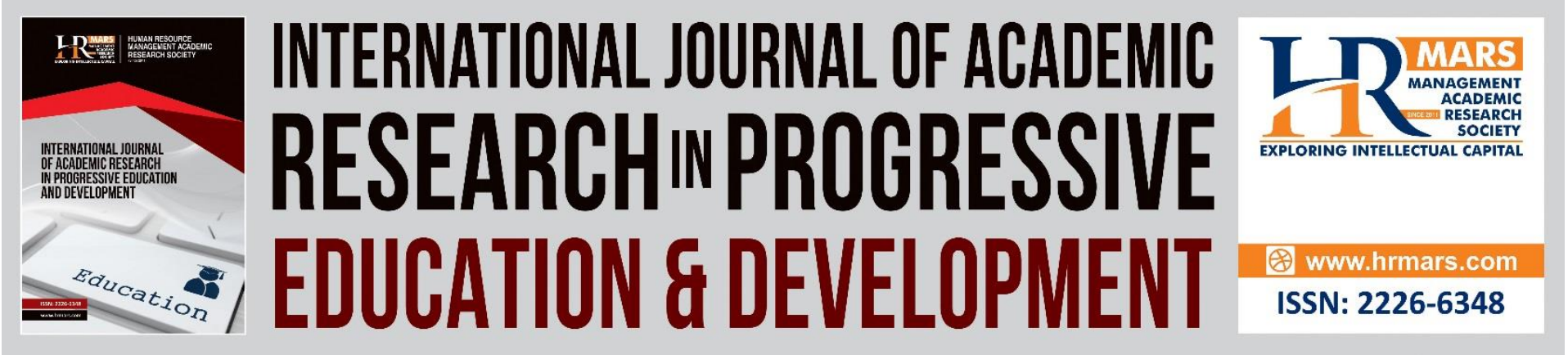

\title{
A Quest for the Self and Identity in Two West African Autobiographies: Mary Ashun's Tuesday's Child and Helene Cooper's the House at Sugar Beach
}

\section{Amma Gyaama Dankwa}

To Link this Article: http://dx.doi.org/10.6007/IJARPED/v10-i3/10569

DOI:10.6007/IJARPED/v10-i3/10569

Received: 05 June 2021, Revised: 12 July 2021, Accepted: 30 July 2021

Published Online: 24 August 2021

In-Text Citation: (Dankwa, 2021)

To Cite this Article: Dankwa, A. G. (2021). A Quest for the Self and Identity in Two West African Autobiographies: Mary Ashun's Tuesday's Child and Helene Cooper's the House at Sugar Beach. International Journal of Academic Research in Progressive Education and Development, 10(3), 275-285.

Copyright: (C) 2021 The Author(s)

Published by Human Resource Management Academic Research Society (www.hrmars.com)

This article is published under the Creative Commons Attribution (CC BY 4.0) license. Anyone may reproduce, distribute, translate and create derivative works of this article (for both commercial and non-commercial purposes), subject to full attribution to the original publication and authors. The full terms of this license may be seen at: http://creativecommons.org/licences/by/4.0/legalcode

\section{Vol. 10(3) 2021, Pg. 275 - 285}




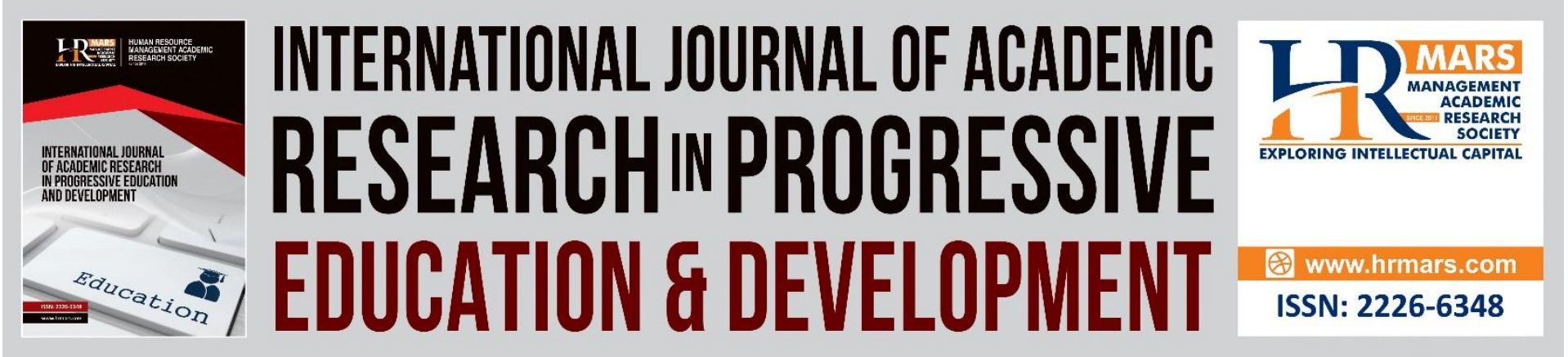

\title{
A Quest for the Self and Identity in Two West African Autobiographies: Mary Ashun's Tuesday's Child and Helene Cooper's the House at Sugar Beach
}

\author{
Amma Gyaama Dankwa \\ Department of Communication Studies, University of Professional Studies, Accra \\ Department of English, University of Ghana, Legon, Accra \\ Email: ama.dankwa@upsamail.edu.gh
}

\begin{abstract}
Studies have offered insights into how autobiography recounts and interprets the writer's past, relying heavily on what the writer has become at the time of writing and invariably, preserving the writer's personality. The current avalanche of autobiographical writings and their attendant studies indicate without a doubt the keen interest in issues about identity and self in purging writers of their mental, emotional and psychological anguish. The study employs close reading to the analysis of the two texts while deliberating on the central thematic ideas. Thus, through textual analysis, a methodical perusal of the two texts provides an opportunity to investigate how Ashun and Cooper chronicle the development of their 'selves' in Tuesday's Child and The House at Sugar Beach respectively. Through reflections on their past experiences, coupled with the historical consciousness they have about their families and communities, they reach a full realization of their selves for a healthy life and well-being. Aspects of their lives that they had initially struggled to come to terms with are embraced as part of their life stories.
\end{abstract}

Keywords: Autobiography, Self, Identity, Historical Consciousness, Retrospection

\section{Introduction}

Extant research to date, albeit limited, have defined autobiography as a story that details events, achievements, disappointments, griefs, the confidential and even failures through the course of the narrator's life. In other words, autobiography refers to the narrator's life as it has been shaped in the course of time (Lopi, 2008; Ebila 2015; Rondot 2016; Samir Mohammad Ahmad 2019). Incontrovertibly, the autobiography can be said to have three basic aspects that are unique to it as a genre: a non - fictional narrative, the protagonist has to be the author and it chronicles the development of the 'self' through reflection (Lopičić 2008; Man 2012). Similarly, Lejeun (1989) explains the autobiography as being about the narrator's own already lived life, which is retold in retrospection. Concurrently, the autobiography narrates past, present and even future events which are fused in as soon as 
the autobiographical narration begins. This element makes the autobiography a complicated narrative. However, this important element of autobiography is often overlooked.

Existing research thus suggests that autobiography is of critical importance because it serves as a quest for a voice, for the self and for an identity (Galanaki et al., 2013; Premalatha \& Deivasigamani, 2018; Schmitt, 2018). Moreover, number three (3) of the seventeen (17) United Nations Sustainable Development Goals targets good health and well-being for the human race. In the quest for self and identity, writers of autobiographies are purged of their emotional, mental and psychological anguish, thereby, promoting and ensuring healthy lives and well-being as projected by the United Nations for all people. Therefore, through retrospection and remembering the past, the writer is able to purge himself of his pains, joys, disappointments, failures, successes, achievements, desires and to come to terms with those aspects of his life that hitherto, had proven difficult or impossible for him to accept as part of his life story (Ebila, 2015; Man, 2012; Nadu, 2018; Samir Mohammad Ahmad, 2019).

In order to address this challenge, the study employs close reading to examine two West African autobiographies: Mary Ashun's Tuesday's Child and Helene Cooper's The House at Sugar Beach to explore how the writers' quest for the 'self' is realized through their reflections on their past, their attachments to place and community. In addition, through textual analysis, the study explores how their historical consciousness determines their personal identity (Samir Mohammad Ahmad 2019; Schmitt 2018; Man 2012).

\section{Discussion and Analysis}

This section engages with some important streams of discussions and analysis on Mary Ashun's Tuesday's Child and Helene Cooper's The House at Sugar Beach. The section gives a brief synopsis of both novels and further gives detailed analysis of both novels. Compared with past research, the section advances the current literature on using autobiography as a quest for a voice, for the self and identity for writers (Samir Mohammad Ahmad, 2019; Schmitt, 2018).

\section{Synopsis of Mary Ashun's Tuesday's Child}

In Tuesday's Child, Mary Ashun (the author) takes us through her birth as narrated to her by her mother, father and maternal grandmother, through to her growing up years in Ghana, West Africa, Britain and then back to Ghana. Ashun's life moves in and out and then back to that of a privileged Ghanaian child and woman. Great effort is made to simultaneously narrate the story of Nana's (Ashun's maternal grandmother) life to find the 'self' that Ashun eventually comes to terms with.

\section{Discussion on the Quest for the Self in Ashun's Tuesday's Child}

Mary Ashun begins her life story with the graphic details of her birth. She has three different accounts from her mother, father and maternal grandmother who were all present at the time. Of the three accounts, that of Nana, Ashun's maternal grandmother is spectacular because Nana tells her that she single - handedly delivered her into the world and her first word, of course, was, 'Nana'. Even with the account given by her mother, Ashun gives Nana a larger than life role to portray her as an indomitable human being who is always in control of affairs and cannot be shaken. It is in this regard that when she finally accepts who she is and finds her 'self' and her identity as a Ghanaian, she links that realization to the role Nana has 
played in her life to bring her to that point. In effect, then, it is Ashun's historical consciousness of her connection to Nana which succeeds in creating in her, a strong sense of attachment to place and community, specifically, Asamankese, Ghana.

When she was barely a month old, the issue of blackness or being black rears its ugly head and will continue to haunt Ashun for several more years to come. Nana keeps her indoors during the day 'for fear of darkening [her] skin beyond an acceptable hue' (20) and when her father asks what an acceptable hue is, she responds, 'so that white people don't run away when they see her' (20). Nana, to all intents and purposes, appears to have been negatively impacted by European socio-cultural and historical representation of the black skin as dirty, sinful, evil and disease-ridden (Jordan 1974; George 1985; Combs 1994). This probably explains why she feels the need to do whatever is possible on her part to keep the baby's skin from darkening 'beyond an acceptable hue'.

Interestingly, Ashun encounters another opposition to her skin colour in Britain by children who must also have been fed the same or similar misconstructions about the African. Her first day at school in Britain is when she is six years old and girls not more than eight years old tell her, 'We've got to flush the brown away ... you're dirty' (33). They cannot think of any better way to do that other than asking her to put her hands in the toilet and flush gallons of water over her hands in vain. The irony is that, Nana herself, is black and believes in the misconstruction of something being wrong with the colour of her skin, thereby perpetuating the decades' old misrepresentation and lending credence to the action of Ashun's accusers and detractors.

Ashun continually has to endure similar denigration of and attacks on her skin colour, 'There were no black people in Bible times' (35), Ms. Collins, her teacher in Britain tells her as the reason she cannot be given the role of Mary in the Nativity play even though she has prepared more than anyone else. 'How come she gets picked? She's black' (36). This is when Ashun gets invited by one of the popular girls for birthday treats at the movies and several of the girls at their school cannot understand why, considering her skin colour. At the movies, Ashun gets asked many questions by the adults, including how she got to England and her response that she came by air so shocks them that they respond, 'Fancy that ... Africans in planes' (36). 'If niggers come here, what's going to become of our neighbourhood' (37) is the reaction of some neighbours of the Ashun family's good friends when the Ashuns start walking their streets. As a result, some of the neighbours move out.

I believe the turning point for Ashun begins when she takes part in the District Sports as the representative for the 400 - metre race and a voice in the crowd yells, 'What's that nigger doin' 'ere? Go back to Africa' (39)! Cathy's parents are there to give her their unflinching support and that, coupled with the humiliation of being constantly rejected and maligned because of her skin colour, spurs her on to speed 'around the tracks like a pack of cheetahs was after [her]' (39). Sobbing, she is more determined than ever to do her best so that 'with all the frustrations possible for an eight - year - old to feel, I felt like I was running for all black people in the world' (39), and sure enough, she wins gold. Ashun's feeling of anger makes her identify with the black race to the extent that she has to fight to redeem their image. Ashun's historical consciousness of her ancestry in being African creates a strong sense of commitment to her race in that instance, resulting in victory for her and her kind. 
Back in Ghana, Ashun begins to have a sense of belonging and of acceptance within minutes of arrival, '. . . everyone wanted to hug us, talk to us, take pictures with us. I hadn't felt so wanted since I was born (46)! This situation is a very different one from her life in Britain which saw some people's rejection of her presence on the basis of her colour whereas, here she is, being welcomed and smothered so much in hugs, it must have been suffocating. This feeling of belonging, coupled with her historical consciousness creates a resolute bond towards the community and place she ultimately grows up in.

However, in the midst of her feeling of belonging, Ashun encounters another situation which throws her into a state of confusion. Her first teacher on their return to Ghana is Mrs. Abankwa who makes her feel out of place due to her British accent. This is how she remembers the feeling:

'She says I think I' $m$ white and that I should stop speaking like a British person because we are in Ghana now. I really was trying desperately to lose the British accent since I felt so out of place. And from the tone of Mrs. Abankwa's voice, if I didn't lose it, it would make me come across like I felt better than her. What a confusing thing in Ghana, we looked like everyone else but just because we didn't sound like everyone else, some people took offense. I guess it wasn't too different from being in England where despite the fact that we spoke like everyone else, we didn't look like everyone else. I wondered if I'd ever belong. $(69,70)$

While in Britain, Ashun's sense of self was something she struggled to identify. She sounded like everyone else but was not like everyone else with regards to her skin colour, for example, and this confused her young mind as to who she actually was and which group of people she could identify with. When they arrive in Ghana, the instant welcome and acceptance she receives settles her mind as to where she belongs and the people she can identify with and so, she comes to terms with who she is. This is why Mrs. Abankwa's attitude completely throws her off track so that in Ghana, she has a sense of belonging but not belonging, just as it was back in Britain.

\section{Internal Conflict and Sense of Belonging}

The issue of internal conflict of understanding who she is, where she belongs and being comfortable with that 'self' is what certainly keeps pulling Ashun back to Nana because Nana represents for Ashun, the pathway to her finding that sense of belonging. When being black and different from everyone else in Britain begins to take a toll on Ashun's family, she writes to Nana asking Nana to tell them (their disparagers) to leave them alone. She has that strong faith in Nana to be able to sort out any problem there is even as young as she is, basically because of the personality she has seen in Nana.

Nana tells her several years later, 'Don't forget where you came from you hear' (206)? This strong statement from Nana has a profound impact on Ashun so that memories of her give her the courage to journey back home to Ghana from North America to claim that identity she shares with her. The historical consciousness Ashun has, is sturdily connected to Nana and inevitably, creates a strong sense of attachment to Asamankese especially, as a place and community she belongs to. This historical consciousness and strong sense of attachment gives her a clear sense of self.

Not surprisingly, her feeling of insecurity and sense of not belonging is acutely felt again when she re - visits the old house in Asamankese after so many years away in Canada without 
visiting even once. She feels 'oddly out of place' (219) and berates herself for not coming back when they were all alive. She yearns for Nana to come out and hug her and tell her she is still okay and Ghanaian. Her imaginary conversation with Nana and Nana's reminder of the proverb about the leopard finally makes her realise that she has not lost a sense of who she is - Ghanaian. 'Rain may fall hard on the leopard's skin, but it cannot wash out the spots. Those rains that fell on - they didn't wash them away after all' $(226,227)$.

In other words, Nana reminds Ashun that although her childhood experiences about belonging but not belonging, both in Britain and Ghana, and her immigrant life in North America have had such a profound effect on her, her spots of having a black skin, belonging to Ghana, being Ghanaian and being accepted as such, has remained and that is what she has gone back for - 'Sankofa' (go back and take it). Ashun journeys back to the very beginning of her life - with Nana - to find her 'self'.

\section{Synopsis of Helene Cooper's the House at Sugar Beach}

In this subsection, we very briefly give the synopsis of Helene Cooper's the House at Sugar Beach. Furthermore, we present critical analysis on the phenomenon of quest for the self as found in the literature.

\section{Synopsis}

Helene Cooper's the House at Sugar Beach transports us to Liberia, West Africa where she grows up in a highly affluent home and society. However, her extremely privileged and comfortable lifestyle comes to an abrupt end with a series of coup d'états engulfing the country and toppling her whole world. Cooper continues her narration from the United States of America where her life sees a reversal of fortune as she struggles to find her 'self' and comes to terms with who she is.

\section{Discussion on Quest for the Self in Helene Cooper's the House at Sugar Beach}

When we are invited into Cooper's life, we are immediately introduced to the ostentatious lifestyle she is accustomed to. She lives in a twenty-two-roomed house which overlooks the Atlantic Ocean that her father has built. It is filled with lots and lots of ivory her mother loves and they have a watchman and other servants:

Shangri-La, Camelot, the Garden of Eden - the Cooper family's perfect and perfectly grand paradise, where John and Calista Cooper could raise their perfect family, cosseted by wellpaid servants, and protected from the ravages of West African squalor and poverty by central air-conditioning, strategically placed coconut trees, and a private water well. (9)

Thus, Cooper and her family live an extremely - privileged lifestyle which is completely different from the life the 'Country People' live - a life of squalor and poverty. For four weeks every July, the Cooper family holiday in Spain, in their own house that Mr. and Mrs. Cooper bought right after they got married. Cooper and her younger sister, Marlene, attend an American school in Liberia which is very expensive. They do not attend a Liberian school in Liberia. She is a great-great-great-great -granddaughter of Elijah Johnson and Randolph Cooper which gives her a ticket into the landed gentry upper class of Africa's first independent country, Liberia. Cooper's historical consciousness creates a strong sense of attachment to 
place and community which gives her a sense of 'self' and identity and a sense of belonging 'somewhere'.

All of the above notwithstanding, Cooper has the perception about the black skin colour that Nana in Ashun's Tuesday's Child has in the sense that she obsesses about light-skin as the superior skin colour in Liberia. There is a barrage of descriptions about light-skin and whiteskin so she describes her mother as being light-skinned with 'long, silky, soft, white people's hair' (13) and her father as also light-skinned. She is darker than her parents 'but still lightskinned by Liberian standards' (14) and her younger sister, Marlene 'could easily be taken for white if it wasn't for her African features' (16). The importance attached to being seen and described as light-skinned is so critical that Cooper is worried when Eunice does not believe that she can also burn like white Marlene.

\section{Identity crisis: Cooper's complex with her black skin}

Evidence from the text suggests that the issue of the supposed inferiority of the black skin features prominently. Consequently, it is this supposed inferiority of the black skin and supposed superiority of the white skin that presents Cooper with an identity crisis (Samir Mohammad Ahmad, 2019). She says, 'The chain started by those two men would eventually separate me from most black people in America, at the same time separating me from most black people in Africa' (29). This is a reference to the choice Elijah Johnson and Randolph Cooper made to be returned to Africa. They made that choice rather than stay on in America as freed slaves and be weighed down by racial stereotypes and inferiority complex about whether they were as good as white people. So, that decision eventually makes an African girl like Cooper, with her privileged status in Liberia, become rejected by fellow poverty-ridden black Liberians but also vilified by black people in America.

This identity crisis haunts her all the way to America. At the University of North Carolina at Chapel Hill, she joins the Carolina Tar Heels 'Because becoming a Carolina Tar Heel meant I could identify myself as something other than being Liberian' (240). Cooper's crisis of finding her 'self' creates as it were, a metaphor of facing two ways for her (Gocking 1999). This is because she is proud of her historical consciousness and attachment to the founders of Liberia, Elijah Johnson and Randolph Cooper and the status it has given her. Yet, she yearns and craves to be like a white person so that provides her a dilemma of facing two ways in her understanding of who she is. Cooper and her younger sister, Marlene, strive so hard in their growing years at the house at Sugar Beach at aping being whites from their oldest sister, Janice. She was at school in England but spent her holidays with them in Monrovia. Cooper writes, 'In my fantasy, I looked fresh and hip and American or British as I swept off the plane after a year living in the States or London' (17). This was her daydream - having an extended stay in America or Britain and returning to Monrovia as a 'been-to' (someone who had had an extended stay in America or Britain and returned to Africa). She imagined being welcomed as a celebrity and would speak with an American accent just as Janice spoke with a British accent.

Eventually, Cooper's strong desire to see herself as something other than Liberian comes on the back of having to straddle two worlds post-April 12, 1980 in America. She has her current 
life in America of going to school every day where no one talks to her, coupled with the total disintegration of her family and flamboyant life.

Then, she has her life of pre-April 12, 1980 which 'was filled with a deep-to-the-bone knowledge that I was somebody and I came from somewhere, a world that Elijah Johnson and Randolph Cooper and my ancestors had built from scratch through blood and sweat' (206). Cooper's pride in her historical consciousness and attachment to place and community has been the lifeline which always gave her a sense of 'self' and of belonging somewhere.

The coup d'état by Doe which was Liberian's first however, shattered that fragile life support she always had. It so overturned the Coopers' well-planned luxurious life that when she, her mother and Marlene are able to sneak safely out of war-torn Liberia, Cooper writes, 'When we climbed aboard Pan Am 150, we were privileged, elite Congo People. When we arrived in Knoxville, we were African refugees' (196). That is the reversal of fortune for the Coopers and most of the Congo People Cooper knew and moved around with in the same circle in Liberia. Her whole family and circle of friends had in one swoop, disintegrated. She had persistently and continually suffered humiliation and rejection connected with her being black and from a war-torn African country from schools in Knoxville to Dudley, Jordan and Chapel Hill. This embarrassment had finally taken its toll. She was ready to identify herself with anything but being Liberian.

The tag of being Liberian had become so distasteful that she eventually could not wait to rid herself of her 'odious Liberian passport' (290). Cooper reaches the point where she realizes that she cannot continue to straddle the two different worlds which includes her current world of being a nobody from nowhere and her old world of being a somebody from somewhere. So, when she receives a call from the Wall Street Journal for an appointment, Cooper joins the world of national journalism that she had craved for so long, leaving Liberia for good and makes a final break.

She had decided that Liberia was not a place where one lived but a place where one died because those of her close family who got out lived - herself, Mommee, Marlene, Vicky, Janice, John Bull, Tello 'them'. while those who stayed died - Uncle Cecil, Daddy, Uncle Julius, Bro. Henry, Mama Grand and Uncle Waldron. The only person who stayed and had stayed alive was Eunice but just so that thoughts and memories of her do not interfere anymore with her daily living, she had moved her into a place deep inside where she keeps Daddy and Bro. Henry, a place where she could visit when she needed the solace of family. She had severed the last link she had - the one in her head and in her heart with the girl who had been her sister since she was seven.

So it was that, Cooper rejects Liberia as her country after she watches Doe have Quiwonkpa executed when he attempts to overthrow Doe. She watches with her friends on television at school in Carolina, Doe's soldiers run around the streets of Monrovia with Quiwonkpa's organs including his penis and heart. Her friends are shocked and wonder what place she comes from and if she .would write an article about what they had just watched. With her face heating up with embarrassment, she shakes her head and responds, 'That place ain't my 
country' (248). Cooper repudiates any connection she has with Liberia as a result of the inhuman acts she witnesses with her friends which have been going on there.

The irony is that while the land of her birth that she once was so proud of is in the throes of yet another war, Cooper is at military boot camp preparing to embed with the US Army to liberate the besieged population of Iraq. She narrates to us:

'While Liberians were crawling on their hands and knees on the floors of what was left of their homes to get away from rockets and grenades, I was hanging out with a five-hundred-strong press corps at the swank Kuwait Hilton Resort, getting anthrax vaccinations and going through training sessions on how to use my gas mask.' $(298,299)$.

In her desire to join the world of national journalism, she goes on a mission with the US Army to Iraq. This is at a time her beloved Liberia has practically been brought to its knees and majority of the citizenry had become beggars in their own country. Ironically, she thinks to herself when in Iraq, a tank runs over the Humvee she is travelling in, 'If I'm going to die in a war, it should be in my own country. I should die in a war in Liberia' (310). Such thoughts eventually result in her going back to Liberia to try to reclaim the self she has lost, the identity she has rejected.

\section{A Sense of Belonging at Last}

On arrival, just like Ashun, she reprimands herself that instead of travelling from Geneva to cover trade talks, to London to visit friends for the weekend or to the Amazon River in Brazil, 'I should have instead been coming here, to Liberia. I should have been coming to here, Liberia, to find Eunice' (316). Back home in Monrovia which looks like a hell-hole, what with no electricity and running water since 1992, city streets jammed with garbage and skinny war orphans with huge-sunken eyes and cheeks running up to the car, she feels she is home even though home is Hell. 'There was something else there too. Pride. Not at what Monrovia had become, but at the fact that it was somehow still there, as proof that I came from somewhere' (321). Cooper's attachment to place and community emanates from her historical consciousness which is as a result of her lineage to Elijah Johnson and Randolph Cooper. This immensely contributes to her realization that she does actually belong somewhere because she originated from somewhere. Regardless of the hell that place may be, it is still somewhere and she comes from there and so she is somebody and not the nobody her years in America had begun to make her feel.

When she eventually tracks Eunice down to Firestone, Eunice crowns Cooper's newfound sense of self and of being able to identify with somewhere, some people and having a historical consciousness with, 'You're home' (329). With this welcome and acceptance from Eunice, Cooper is ready to face the impossible and confront her childhood fears at Sugar Beach. She is ready to purge herself of her pains and even ask Eunice for forgiveness for their neglect of her all those years. Together with Eunice and her husband, Walker, they journey back in time to Sugar Beach which was turned into an execution ground by Doe but has now been taken over by squatters. 
DEVELOPMENT

Vol. 10, No. 3, 2021, E-ISSN: 2226-6348 ㄷ 2021 HRMARS

\section{A mother's sacrifice and lost dignity}

Cooper is finally able to relive the night of her mother's rape by several soldiers, the night her mother sacrificed her dignity and sanity for her girls - Cooper, Marlene and Eunice - to demonstrate the selfless love - which is devoid of the self - of a mother for her children. Now, twenty-three years later, Cooper dares to enter the recreation room where it had happened, wondering the exact spot. In Cooper's own words:

Neither Eunice nor I said a word while we drifted around downstairs. There was nothing to see; yet there was everything to see. My mother had made a stand here. She had fought for us. She had fought for her daughters to remain children, and even though that night had seen the end of my childhood, still, somehow, she had won. Weren't Eunice and I standing here as proof? (344)

Her mother had fearlessly stood her ground to ensure that her daughters remained the children they were, no matter the cost, which of course, was her self-esteem, pride and emotional stability. She suffers the pain, shame, humiliation and emotional agony that the traumatic experience that night would have held for her girls - she endures it all for them.

Cooper, at last, comes face to face with the death of her childhood that the rogues and rapists had hijacked so that all the memory she has left of Sugar Beach is the memory of one night. She says, 'My childhood was more than that. It was who I am. And I wanted it back' (340). Cooper finally comes full circle in her quest for who she is. She finds her 'self' back at Sugar Beach, the great-great-great-great-granddaughter of Elijah Johnson and Randolph Cooper, the founders of Liberia and, she is a sister to Eunice. Leaving Sugar Beach for good, Cooper has a feeling of sorrow and euphoria but can with Eunice, laughingly sing their doctored version of 'Blessed Assurance'.

\section{Conclusion}

Within this paper, the study explored the phenomenon of the quest for the 'self' in Mary Ashun's Tuesday's Child and Helene Cooper's The House at Sugar Beach. In particular, the study examined how the authors presented the idea of the quest for self and identity and interpreted the results to suggest that their quest is realized through their reflections on their past, their attachments to place and community and in addition, their historical consciousness. Perhaps even of more interest is the fact that through retrospection and remembering the past, the writers are able to purge themselves of their pains, disappointments and failures but celebrate their joys, successes, achievements and desires to ensure a healthy living and well-being as targeted by number three (3) of the United Nations seventeen (17) Sustainable Development Goals. Their remembering of their past deal with aspects of coup d'états and their attendant impact on their lives. Though for Cooper, the impact is much more devastating and life-changing than Ashun, it still can be seen as something they have in common, in addition to their crisis of who they are and where they belong. They are also able to come to terms with those aspects of their lives that hitherto, have proven difficult or impossible for them to accept as part of their life stories 


\section{References}

Ashun, M. (2015). Tuesday's Child. Accra: Type Publishers. ISBN: 9988224494; 9789988224493

Cooper, H. (2008). The House at Sugar Beach. New York: Simon and Schuster. ISBN-13: 9780743266253

Ebila, F. (2015). "A proper woman, in the African tradition": The construction of gender and nationalism in Wangari Maathai's autobiography Unbowed. Tydskrif Vir Letterkunde, 52(1), 144-154. https://doi.org/10.4314/tvl.v52i1.10

Galanaki, E., Papalexandris, N., Halikias, J., Galanaki, E., Papalexandris, N., Halikias, J., Laiho, M. (2013). Gender in Management : An International Journal Article information :

Lopi, V. (n.d.). Autobiography as Identity Quest :

Man, P. De. (2012). as De-facement Autobiography. 94(5), 919-930.

Nadu, T. (2018). International Journal Online of Humanities (IJOHMN ) ISSN : 2395 - 5155 Volume 4, Issue 1, February 2018 ISSN : 2395 - 5155. 4(1), 1-10.

Premalatha, M., \& Deivasigamani, T. (2018). Quest for Identity in Jamaica Kincaid's The Autobiography of My Mother. II(March), 153-158.

Rondot, S. R. (2016). "Bear Witness" and "Build Legacies": Twentieth- and Twenty-FirstCentury Trans* Autobiography. A/b: Auto/Biography Studies, 31(3), 527-551. https://doi.org/10.1080/08989575.2016.1183339

Ahmad, S. M. N. (2019). Quest for Identity in Jean Paul Sartre's Words and Maxine Hong Kingston's The Woman Warrior. 206-180), 9(5, ?. https://doi.org/10.21608/jssa.2019.75639

Schmitt, A. (2018). From Autobiographical Act to Autobiography. Life Writing, 15(4), 469-486. https://doi.org/10.1080/14484528.2018.1478598 